\title{
on_education
}

Journal for Research and Debate

\section{cultivating connectedness and generosity in universities: a view of early career academic experiences in aotearoa, new zealand}

\author{
Kathryn A. Sutherland
}

\begin{abstract}
Academic work is intense. Academics beginning their careers now carry an unprecedented weight of expectation across a wide range of roles. They must excel as teachers, researchers, supervisors, managers and public intellectuals who are technologically savvy, culturally aware, entrepreneurial and capable of competing on an international scale for students, research funds, patents, publication opportunities, media time, rankings, awards and tenure. Academics must also account for all these activities in a performative environment that is more managerial, market-oriented and international than ever before.
\end{abstract}

Introduction

Academic work is intense. Academics beginning their careers now carry an unprecedented weight of expectation across a wide range of roles. They must excel as teachers, researchers, supervisors, managers and public intellectuals who are technologically savvy, culturally aware, entrepreneurial and capable of competing on an international scale for students, research funds, patents, publication opportunities, media time, rankings, awards and tenure. Academics must also account for all these activities in a performative environment that is more managerial, market-oriented and international than ever before. Much higher levels of stress are reported by academics than professionals in other careers, partly due to the weight of their wide-ranging and demanding responsibilities (Guthrie et al., 2017). Yet, academics also experience significant freedom, flexibility and autonomy in comparison with other jobs. So how might new academics be encouraged to embrace the flexibility and autonomy of their careers, without resorting to selfishness and competitiveness? And how might a culture of connectedness and generosity be promoted in an increasingly fragmented academic world? This essay reflects on the experiences of early career academics (ECAs) in Aotearoa New Zealand universities, suggesting ways of creating supportive and collegial working environments for newcomers to academia.

Academia in the $21^{\text {st }}$ century

Academics starting work in universities now face an academic milieu quite different from the one in which their senior colleagues served and taught. Government funding for higher education in many countries now comes with expectations of accountability and performance on an unprecedented scale. University governing councils in New Zealand, for example, must align their plans and priorities with those of the government's Tertiary Education Strategy to attract and guarantee ongoing funding for their teaching endeavors (Universities NZ, 2018). Universities also take part in 
a six-yearly, performance-based funding exercise for research, which vets institutions' research outputs, contributions, external funding successes, and postgraduate completions (TEC, 2018). They also compete alongside thousands of other universities worldwide for recognition in increasingly visible, but often maligned, international ranking systems, which influence international students when choosing institutions. (International students pay much higher course fees than domestic students, so they potentially represent a valuable income stream for many universities.)

In this marketized higher-education environment, it is not enough for individual academics to simply excel at supporting learning through innovative and engaging teaching. They must do this for increasing numbers of students from evermore diverse backgrounds. Not only must twenty-first century academics relentlessly seek external funding to conduct their research, they must also justify the impact of their research - proving that it is being read, cited, replicated, adapted, patented and shared widely, changing thoughts and lives. Academics need to be familiar with an array of sophisticated, ubiquitous technologies and media, for both teaching and research. They must know how to appropriately record their teaching and research achievements in order to have them "count" in externally imposed, performance-based funding exercises. They need to supervise growing numbers of doctoral and other postgraduate students, co-publishing with them and providing teaching opportunities, and helping them cultivate international networks and source potential job opportunities. Academics must be entrepreneurs, fundraisers, recruiters, event planners, board members, editors, reviewers, grant writers, conference organizers, grant assessors, examiners and public intellectuals, all of which must be done on an international scale, not just within their own department or city.

Academia is clearly a highly demanding job. It is also a privilege. Along with the diverse range of roles and responsibilities already listed, comes a significant helping of long-fought-for and fiercely protected autonomy and freedom. Academia is renowned for its flexible working hours, spaces and expectations, and many academics will vouch that it is a privilege to immerse themselves in the pursuit of answers to questions that fire imaginations, solve world problems, inspire students, encourage justice, and change thinking and practice. Yet, such pursuits often mean that work is life for many academics. The much-vaunted freedom and autonomy of academia are often accompanied by unwanted incursions of work-stressors into home lives; compromised time management despite or sometimes because of - the flexible working hours; and a lack of collegiality wrought by the need to compete with colleagues for funding and recognition. Nowadays, embarking on a successful academic career (should one be fortunate enough to secure a permanent post) is daunting to say the least (Sutherland, 2017). It should not be crippling, though. Nor should success, however it is defined, come at the expense of individuals' (or families') physical and mental health or happiness.

As a contribution to this special issue on academic lives around the world, I share below some findings from my research with ECAs in Aotearoa New Zealand. This research paints a picture of academic lives worth pursuing and celebrating but accompanied by challenges and risk. A concerted effort is needed to provide more generous support for new colleagues, and this paper will suggest ways of creating supportive and connected working environments in universities.

What matters to ECAs?

I recently asked ECAs in universities across Aotearoa New Zealand to describe their academic lives. Information was sought on: qualifications, background, prior experience, teaching, research and service activities, output and awards; perceived importance and effectiveness of institutional 
policies, support, resources and services; satisfaction and well-being; and what mattered to them as academics. Detailed methods and results can be read in Sutherland (2018). Some of the findings are shared here: what academics said mattered most to them, and what they needed to do to be effective and happy in their jobs.

Not surprisingly, autonomy prevails in the working lives of ECAs in New Zealand universities. When asked to rate the importance of various policies, services, resources, support and working relationships, ECAs ranked "Opportunities to make decisions about the direction of my own research and teaching" as the most important. Most of the other items ranked as important (by 95\% or more of respondents) were relational, such as contact with senior colleagues and heads of department, support and feedback, provision of mentoring opportunities and support from administrative staff. The combination of desire for autonomy and connectedness also emerged later in the survey, when respondents were asked to identify issues of personal importance to them: "Autonomy in my job" was second only to "My family or relationships outside work". Other issues of personal importance included making a positive contribution to society, job security and seeing students succeed. Earning a high salary, early professorship, public recognition and the status of having an academic job did not feature as being personally important.

Academics in Aotearoa New Zealand are not driven by status or salary, but instead value autonomy alongside support from their heads of department and senior colleagues. They also desire adequate funding and resources to pursue their research and connect with disciplinary colleagues. Their loyalties lie with their disciplines - not with institutions - and their interests lean towards research more than teaching, as do their time commitments: they report spending $44 \%$ of their time on research, $35 \%$ on teaching, and $21 \%$ on service and administration (not quite the traditional 40-40-20 split).

Academics are productive and confident researchers and teachers. Just $6 \%$ of all respondents had not yet published anything at all, compared with $20 \%$ of academics worldwide (Teichler et al., 2013, p. 146). The majority teach three or more courses per year, supervise postgraduate students, attend national and international conferences, and report encouragingly high levels of confidence in their teaching and research. They also enjoy the challenges associated with their jobs and appear to be significantly more satisfied than academics in other countries around the world (Bentley et al., 2013).

It is apparent, however, that these ECAs do not feel particularly well-funded or supported in their work and find the stressors of the job not only detrimental to their overall well-being, but also a considerable threat to the contentedness of their lives outside work.

What do ECAs need?

ECAs in Aotearoa New Zealand report inadequate levels of funding for teaching and research, insufficient opportunities to meet with disciplinary colleagues beyond the institution, ineffective professional development opportunities, and disparity in the provision and encouragement of support from their departments, faculties and universities. In addition to this frustration at feeling inadequately equipped or supported, ECAs also report that they take work home more of ten than they would like, worry about work-related issues too much, feel exhausted at the end of the working week, and that their families think they do not spend enough time with them. These findings raise important questions about what universities could do to alleviate some of the burdens on ECAs, and 
how universities might address the need for connectedness and desire for autonomy, enabling academics to enjoy both work and home life.

Firstly, it does not follow that a desire for autonomy necessarily translates into a dismissive attitude towards engaging in continuing professional development in academia. The ECAs in this research were clear about the importance of professional development for their careers, identifying the following as important (though not always effectively implemented): formal and informal mentoring, peer observation of teaching, conference attendance, research leave and a formal orientation program for new academics. Furthermore, those who were more active in professional development were also more confident teachers and researchers. ECAs desire more targeted, nuanced and timely professional development, however (more on this below).

Secondly, there is a need to recognize the importance of heads of department in contributing to both the personal well-being and career trajectories of ECAs. Heads of department can play a significant role in helping new academics navigate the intricacies of academic careers and process the avalanche of information about policies, training, resources and services that they receive in their first few weeks in the job. Heads of department can also help prioritize opportunities and broker relationships with other key people in the department, university and discipline. However, without adequate training and support themselves, not all heads of department are up to these tasks.

Thirdly, ECAs need all aspects of academic life to be adequately rewarded and recognized. Although they report a preference for research as opposed to teaching, this does not mean that they want their teaching to go unrecognized or under-supported. Rather, the vast majority of respondents in this study called for better rewards for both teaching and research, and better recognition for the contributions of individuals to the work of the university.

Meeting these needs: an example from one university

Victoria University of Wellington has moved towards more holistic recognition of the diverse roles and expectations in academic careers, with the introduction of a new "Academic Career Framework". This expresses the work of academics in four key areas, explained here in English with the Māori translation in parentheses (Māori are the indigenous people of Aotearoa New Zealand): teaching (ako), research (rangahau), external engagement (ruawhetu) and leadership (hautūtanga). This framework acknowledges all four areas as being integral to the work of the university and its academic staff. Whether their strengths are in teaching, research, engagement or leadership, or spread equally across all four areas, academic staff can see how their work contributes to the overall framework and know that it is valued. The university expects academics to engage with all four components of the framework to varying degrees, depending on their seniority, experience, preferences and strengths. Furthermore, the university now recognizes and rewards all key areas through updated promotion criteria (formerly weighted strongly in favor of research), and through revised professional development and career planning processes. One feature is a new program for ECAs, which embraces a holistic approach to academic career development.

Three key principles underpin the Victoria Early Career Academic Programme (VECAP): a holistic understanding of scholarship (Boyer, 1990; Glassick et al., 1997); whanaungatanga (a sense of connectedness and relationships); and manaakitanga (support and respect for others). Ernest Boyer's influential work in the 1990s proposed that scholarship should not just be seen as a research activity, but as having four distinct and interlinked dimensions, explained in recent research by Matthews et 
al. (2014, p. 122):

Boyer's notion of the "true scholar" (one participating in an academic career that unfolds in seasons of overlapping and varying involvement in research, teaching, engagement and integration) [is] dynamic and not limited to a single "truth" for all academic careers.

Through VECAP, the university encourages ECAs to develop themselves as scholars in the fullest sense of the word. VECAP provides opportunities for independent and collaborative learning about all aspects of the academic role, including teaching, research, leadership, academic citizenship and engagement. The program encourages individual reflective practice and enables the creation of supportive communities of peers and mentors. This support is underpinned by whanungatanga and manaakitanga, two of six principles from Māori culture lying at the heart of the university's strategic plan (VUW, 2014). The university's Learning \& Teaching Strategy (VUW, 2016) provides useful definitions for each concept:

The Māori term whanaungatanga is based on the root word whanau (extended family). It acknowledges the close relationships and bonds that are formed through collective experiences and provide a sense of belonging (VUW, 2016, p. 6).

Manaakitanga conveys notions of hospitality based on the compound word manaaki, which means to support and respect. It also encapsulates the root word mana, which translates as reputation, influence and authority. Thus, in Māori tradition, a person could enhance their mana by being generous and sharing with others (VUW, 2016, p. 7).

The principles of whanaungatanga and manaakitanga, which underpin the VECAP approach, encourage participants to work collectively, generously and respectfully. The program itself consists of the following components:

Table 1: VECAP components 


\begin{tabular}{|c|c|c|}
\hline Component & Timing & Purpose \\
\hline Two 2-day, off-site retreats & $\begin{array}{l}\text { One at the beginning and } \\
\text { another two-thirds of the way } \\
\text { through the program. }\end{array}$ & $\begin{array}{l}\text { To encourage whanaungatanga } \\
\text { (sense of connectedness and } \\
\text { relationships) and demonstrate } \\
\text { hospitality (an aspect of } \\
\text { manaakitanga), off-campus in a } \\
\text { congenial setting. Retreats } \\
\text { focus on goal setting, } \\
\text { prioritizing, cohort building and } \\
\text { reflection on scholarly roles and } \\
\text { habits. }\end{array}$ \\
\hline $\begin{array}{l}\text { Launch event with Heads of } \\
\text { Department, Associate Deans } \\
\text { and Senior Leaders }\end{array}$ & $\begin{array}{l}\text { After the retreat and before the } \\
\text { start of term. }\end{array}$ & $\begin{array}{l}\text { To allow senior colleagues to } \\
\text { manaaki VECAP participants } \\
\text { (show respect and support), } \\
\text { through round-table, faculty- } \\
\text { based discussions and a social } \\
\text { event. }\end{array}$ \\
\hline $\begin{array}{l}\text { Whole cohort meetings and } \\
\text { workshops }\end{array}$ & $\begin{array}{l}\text { Monthly: the first hour is a group } \\
\text { meeting; the second hour } \\
\text { features a workshop, seminar or } \\
\text { guest speaker. }\end{array}$ & $\begin{array}{l}\text { To encourage manaakitanga } \\
\text { (support and respect for others) } \\
\text { through sharing of challenges } \\
\text { and highlights. Monthly tasks } \\
\text { are also discussed and } \\
\text { workshopped. }\end{array}$ \\
\hline Monthly tasks & $\begin{array}{l}\text { Distributed at each monthly } \\
\text { meeting and discussed at the } \\
\text { next meeting. }\end{array}$ & $\begin{array}{l}\text { To sustain momentum between } \\
\text { meetings; to encourage } \\
\text { reflection on academic roles. }\end{array}$ \\
\hline Peer mentoring trio/quartet & Held monthly. & $\begin{array}{l}\text { To encourage whanaungatanga } \\
\text { through peer support, inter- and } \\
\text { cross-disciplinary fertilization of } \\
\text { ideas, and peer review of tasks. }\end{array}$ \\
\hline $\begin{array}{l}\text { Meetings with Heads of } \\
\text { Department }\end{array}$ & $\begin{array}{l}\text { Held intermittently (at least } \\
\text { two). }\end{array}$ & $\begin{array}{l}\text { Academic career planning, } \\
\text { identification of resource needs } \\
\text { and pastoral care where desired. }\end{array}$ \\
\hline Additional workshops & As requested. & $\begin{array}{l}\text { Just-in-time approach to } \\
\text { professional } \\
\text { needs. }\end{array}$ \\
\hline $\begin{array}{l}\text { Participation in the university's } \\
\text { mentoring scheme (voluntary) }\end{array}$ & $\begin{array}{l}\text { Continues throughout the year } \\
\text { (regularity agreed by the mentee } \\
\text { and mentor). }\end{array}$ & $\begin{array}{l}\text { To demonstrate manaakitanga } \\
\text { by senior colleagues, and } \\
\text { expose participants to different } \\
\text { ideas and approaches to } \\
\text { academic life, habits, and } \\
\text { careers. }\end{array}$ \\
\hline
\end{tabular}

Monthly workshops or seminars include all aspects of the academic role outlined in the Academic Career Framework and other topics, including:

- Rangahau: Research Planning and Grant Funding (round-table with Research Development Advisers);

- Hautūtanga: Service and Academic Citizenship (with a panel of senior leaders);

- Akoranga: Teaching (workshops led by staff from the Centre for Academic Development);

- Rangatiratanga (Leadership): Autonomy, Freedom and Time; 
- Ruawhetu: Enacting the Critic and Conscience Role;

- Whanaungatanga: Building Collaborations (with a panel of former participants).

Monthly sessions also tie in with tasks assigned at the previous meeting, which are completed either individually or in collaboration with peer-mentoring trios or quartets. Table 2 outlines the tasks assigned to participants over the course of the year and lists the kinds of additional workshops that participants have requested (not all are offered every year).

Table 2: Sample monthly tasks and additional workshop topics

\begin{tabular}{|c|c|c|}
\hline & Monthly Tasks & Additional Workshops \\
\hline - & $\begin{array}{l}\text { Interviewing successful academics (within } \\
\text { and beyond the institution) about 'success } \\
\text { in academia' and their own career paths; } \\
\text { Keeping a time-use log; } \\
\text { Preparing a draft promotion application, } \\
\text { research grant proposal, or teaching award } \\
\text { portfolio; } \\
\text { Peer-to-peer teaching observations; } \\
\text { Logging a minimum of } 30 \text { minutes' writing } \\
\text { time per day for at least a month; } \\
\text { Investigating various service opportunities; } \\
\text { Writing a letter to next year's participants. }\end{array}$ & $\begin{array}{l}\text { - } \quad \text { Speed Reading } \\
\text { - } \quad \text { Contributing to Academic Journals } \\
\text { - } \quad \text { Preparing a Book Proposal } \\
\text { - } \quad \text { Developing a Social Media Presence } \\
\text { - } \quad \text { The Importance of Feedback in Teaching, } \\
\text { - } \quad \text { Research and Leadership } \\
\text { - } \quad \text { A Conversation with the Dean }\end{array}$ \\
\hline
\end{tabular}

This holistic program has affected participants and the institution in several important ways. Having completed VECAP (or its predecessor, a faculty-based program called Developing Scholarly Habits), participants have seen significant improvements in confidence, research submissions and output, collaborative activities and support, work-life balance, commitment to academia and overall satisfaction (Sutherland \& Willis, 2013). One participant sums up these benefits well in the following quotation from an end-of-program questionnaire:

"[It] has been pivotal for me in gaining confidence; every week was valuable in ways great and small. I really appreciated being able to safely vent anxieties, ask "stupid" questions and listen to other people discuss ideas that I had never even considered. It has made me feel blessed, assured, distracted (in a good way) and part of a vital community."

There are also gains for the university as ECAs who have completed the early career program show greater loyalty to the university than previously. Anecdotally, senior leaders also report more invested engagement from ECAs within the university's decision-making processes (attending the Faculty Board or Academic Board, for example, or serving on working parties and committees). Participants recognize that the program shows the university's commitment to their well-being and career development:

"I think the main strength of the program comes in meeting both a peer group and in meeting key senior people from around the university...To be honest, just the existence of the program is a strength as well - it says a lot about Vic and how it treats its academic staff. It's not just a 'live-andlet-die' mentality." 
VECAP is an example of how universities might take a more generous approach to connecting with and supporting ECAs, but more is required than simply offering professional development, no matter how timely or useful. Academics must treat each other with respect, generosity and care. As Hava Tirosh-Samuelson asserted earlier this year (2018, p. 4), academics should not obsess about being "the best". Rather, they should focus on being "more humane [and] caring, less smug, callous, cruel, or indifferent". We must listen carefully and generously to what our early career colleagues say they need - really listen. We cannot just let their voices shout into winds that blow carelessly or harshly past; we need to actually hear what they say and respond, and allow change to happen.

\section{References}

Bentley, P. J., Coates, H., Dobson, I. R., Goedegebuure, L., \& Meek, V. L. (2013b). Academic job satisfaction from an international comparative perspective: Factors associated with satisfaction across 12 countries. In Bentley, P. J. et al. (Eds.), Job Satisfaction around the Academic World (pp. 239-262). Dordrecht: Springer.

Boyer, E. L. (1990). Scholarship reconsidered: Priorities of the professoriate. Princeton NJ: Carnegie Foundation for the Advancement of Teaching.

Glassick, C. E., Huber, M. T., \& Maeroff, G. I. (1997). Scholarship assessed: Evaluation of the professoriate. San Francisco: Jossey Bass.

Guthrie, S., Lichten, C., van Belle, J., Ball, S., \& Hofman, J. (2017). Understanding mental health in the research environment: A Rapid Evidence Assessment. Cambridge: RAND Europe.

https://royalsociety.org/ /media/policy/topics/diversity-in-science/understanding-mental-health-in-t he-research-environment.pdf.

Matthews, K. E., Lodge, J. M., \& Bosanquet, A. (2014). Early career academic perceptions, attitudes and professional development activities: questioning the teaching and research gap to further academic development. International Journal for Academic Development, 19(2), 112-124.

Sutherland, K. A. (2017). Constructions of success in academia: An early career perspective. Studies in Higher Education, 42(4), 743-759.

Sutherland, K. A. (2018). Early career academics in New Zealand universities: Challenges and prospects in comparative perspective. Cham: Springer.

Sutherland, K. A., \& Willis, D. (2013). A relational and holistic approach to the changing academic environment: A faculty-based academic development programme for early career academics. In Macdonald, R. (Ed.), Supporting Educational Change (pp. 39-42). London: SEDA.

Teichler, U., Arimoto, A., \& Cummings, W. K. (2013). The changing academic profession. Dordrecht: Springer.

Tertiary Education Commission (TEC). (2018). Performance-based research fund. https://www.tec.govt.nz/funding/funding-and-performance/funding/fund-finder/performance-basedresearch-fund/. Retrieved November 01, 2018.

Tirosh-Samuelson, H. (2018). In praise of human dignity: The humanities in the age of Big Data. On Education. Journal for Research and Debate, 1(2). https://doi.org./10.17899/on_ed.2018.2.4.

Universities NZ. (2018). About the university sector. https://www.universitiesnz.ac.nz/about-university-sector. Retrieved November 01, 2018.

Victoria University of Wellington (2016). Learning and Teaching Strategy: Te Rautaki Maruako 2017-2021. https://www.victoria.ac.nz/documents/policy/strategies/learning-teaching-strategy.pdf

Victoria University of Wellington (2014). Strategic Plan. https://www.victoria.ac.nz/documents/policy/strategies/strategic-plan.pdf

\section{Recommended Citation}


Sutherland, K.A. (2018). Cultivating connectedness and generosity in universities: a view of early career academic experience in Aotearoa, New Zealand. On Education. Journal for Research and Debate, 1(3). https://doi.org/10.17899/on_ed.2018.3.8

\section{Download PDF version}

Do you want to comment on this article? Please send your reply to editors@oneducation.net. Replies will be processed like invited contributions. This means they will be assessed according to standard criteria of quality, relevance, and civility. Please make sure to follow editorial policies and formatting guidelines.

\section{kathryn a. sutherland}

Dr. Kathryn Sutherland is an associate professor in higher education and an academic developer at Victoria University of Wellington in Aotearoa New Zealand, and a Principal Fellow of the Higher Education Academy. This essay summarises research published in her recent book, Early Career Academics in New Zealand: Challenges and Prospects in Comparative Perspective (Springer, 2018). https://orcid.org/0000-0002-2629-7880 